\title{
Ciliary Neurotrophic Factor Reduces the Proliferation and Promotes the Differentiation of TH-MYCN Transformed Sympathoadrenal Progenitors
}

\author{
John DeWitt Anthony Pappas Rae Nishi \\ Department of Neurological Sciences and Neuroscience Graduate Program, University of Vermont, Burlington, Vt., USA
}

\begin{abstract}
Key Words
Neurite growth · Differentiation $\cdot$ Neuroblastoma .

Neurotrophic factor $\cdot$ Neurotrophin
\end{abstract}

\begin{abstract}
Neuroblastoma is a childhood cancer caused by the transformation of sympathoadrenal progenitors. By following the formation of tumors in homozygous TH-MYCN mice, an established mouse model of neuroblastoma, we were able to capture transformed cells prior to the formation of large, vascularized tumors in order to determine the responsiveness of cells to neurotrophic factors. We discovered that the ciliary neurotrophic factor (CNTF) receptor is abundantly expressed in tumor cells from these mice. Furthermore, CNTF but not nerve growth factor, brain-derived nerve growth factor, neurotrophin 3, or glial cell line-derived neurotrophic factor - promoted neuronal differentiation and withdrawal from the cell cycle. Thus, the transformation of sympathoadrenal progenitors by MYCN overexpression differentially affects responsiveness to neurotrophic molecules.
\end{abstract}

(C) 2014 S. Karger AG, Basel

\section{Introduction}

Neuroblastoma, a cancer of childhood, arises from sympathoadrenal progenitor cells and exhibits heterogeneity in responses to neurotrophic factors. The prognosis of outcomes from neuroblastoma is stratified into low-, intermediate-, and high-risk categories [1] based on the biological heterogeneity of the disease. Regressive, benign tumors express high levels of the high-affinity nerve growth factor (NGF) receptor TrkA, while aggressive stage 4 metastatic tumors are heterogeneous, with the only consistently observed biomarker a 30 - to 100 -fold amplification of MYCN. Over $70 \%$ of the MYCN-amplified tumors express TrkB [2]. Furthermore, the transfection of SY5Y neuroblastoma cells with the TrkA receptor confers the ability to differentiate in response to NGF [3], while, conversely, transfection with the TrkB receptor promotes metastasis and renders these cells resistant to chemotherapeutics [4]. In addition to TrkA and TrkB, other growth factor pathways have been shown to be important in determining neuroblastoma tumor cell phenotypes. The activation of the epidermal growth factor receptor promotes proliferation in SY5Y and NLF cells [5], and SMS-KCNR cells differentiated by retinoic acid express transforming growth factor- $\beta_{1}$ and its receptors [6]. Some neuroblastoma cell lines also express receptors for ciliary neurotrophic factor (CNTF) signaling, including CNTFRa, GP130, and leukemia inhibitory factor receptor- $\beta$ (LIFR $\beta$ ); however, the responses to CNTF and CNTF-related ligands are not well understood.

CNTF, originally discovered as a polypeptide that supports the survival of embryonic chicken ciliary ganglion neurons, has a wide variety of biological activities in the nervous system. A member of the neuropoietic cytokine

\section{KARGER}

E-Mail karger@karger.com

www.karger.com/dne
(C) 2014 S. Karger AG, Basel

0378-5866/14/0365-0422\$39.50/0
Rae Nishi

Department of Neurological Sciences, University of Vermont

HSRF 406, 149 Beaumont Avenue

Burlington, VT 05405 (USA)

E-Mail Rae.Nishi@med.uvm.edu 
family, CNTF signals by complexing with an alpha coreceptor (CNTFR $\alpha$ ), LIFR $\beta$, and GP130 [7]. CNTF promotes the survival of sympathetic, sensory, motor, retinal, and hippocampal neurons [8-10]. Furthermore, CNTF induces astrocytic differentiation of O2A precursors and causes profound weight loss when injected systemically $[11,12]$. In mature neurons, CNTFRa is ubiquitously expressed, yet the expression of the ligand, CNTF, is more restricted [13]. Although chicken CNTF can be secreted, murine and human CNTF are not [14]. Thus, in mammals, CNTF accumulates intracellularly in myelinating Schwann cells and astrocytes, suggesting that it is released by injury to support neural regeneration.

Previously, a mouse model of neuroblastoma, generated by targeting the expression of MYCN to the neural crest lineage using the rat tyrosine hydroxylase $(\mathrm{TH})$ promoter [15], demonstrated that the overexpression of MYCN is sufficient to cause neuroblastoma; this model has been useful in studying the earliest cellular and molecular changes that may occur in the genesis of $M Y C N$ amplified neuroblastoma $[16,17]$. One hundred percent of $129 / \mathrm{SvJ}$ mice homozygous for the TH-MYCN transgene develop tumors by 6.5 weeks of age. These tumors show typical histopathological features of human neuroblastoma [18], as well as genetic aberrations similar to those found in the human disease $[19,20]$. The process by which these tumors develop at sites where sympathoadrenal progenitors coalesce is not well understood. In addition, the responsiveness of TH-MYCN tumor cells to growth factors has not been examined in detail. By following the formation of tumors in homozygous $\mathrm{TH}$ MYCN mice, we were able to capture transformed cells prior to the formation of large, vascularized tumors in order to determine the responsiveness of cells to neurotrophic factors. We report that these cells fail to respond to neurotrophins but retain their responsiveness to CNTF, and that the application of CNTF induced these cells to withdraw from the mitotic cycle and morphologically differentiate into neurons.

\section{Materials and Methods}

\section{Ethics Statement}

This study was carried out in strict accordance with the recommendations in the Guide for the Care and Use of Laboratory Animals published by the National Institutes of Health. The protocol was approved by the Institutional Animal Care and Use Committee of the University of Vermont (Animal Welfare Assurance No. A3301-01; IACUC protocol No. 07-114). Every effort was made to minimize the suffering of the animals used.

Differentiation of TH-MYCN Tumor

Cells by CNTF
Mice

Three homozygous breeding pairs of TH-MYCN mice [15] on the $129 / \mathrm{SvJ}$ background were obtained by material transfer from the Mouse Models of Human Cancers Consortium at the National Cancer Institute. Mice homozygous for the human MYCN gene were used for all experiments involving TH-MYCN tumor removal and growth in culture.

\section{Immunostaining}

Tumors were removed and immersion fixed overnight in Zamboni's fixative [ $4 \%(\mathrm{w} / \mathrm{v})$ paraformaldehyde, $15 \%(\mathrm{v} / \mathrm{v})$ picric acid in $0.1 \mathrm{M}$ sodium phosphate buffer, $\mathrm{pH}$ 7.4]. The tumors were washed with PBS to remove the fixative and equilibrated in $15 \%$, and then $30 \%$, sucrose overnight at $4^{\circ} \mathrm{C}$. Tissue sections of $20 \mu \mathrm{m}$ thickness were cut using a Microm HM 560 cryostat (Thermo Scientific) and mounted on SuperFrost Plus slides (Fisher Scientific). The sections were postfixed for $15 \mathrm{~min}$ in Zamboni's fixative and placed into blocking solution [ $1 \times$ PBS consisting of $10 \%(\mathrm{v} / \mathrm{v})$ heat-inactivated horse serum (Invitrogen), 0.5\% Triton X-100 (Sigma), and 0.1\% sodium azide (Fisher Scientific)] overnight at $4^{\circ} \mathrm{C}$. They were stained with primary antibodies overnight at $4^{\circ} \mathrm{C}$, followed by secondary antibodies for $3 \mathrm{~h}$ at room temperature (see below for the specific antibodies). Slides were then incubated in PBS plus Hoechst (1: 2,000; Invitrogen) for $5 \mathrm{~min}$ at room temperature to stain nuclei and mounted with Mowiol (EMD Millipore). After staining, the coverslips were mounted on slides with PermaFluor (Thermo Scientific) containing Hoechst $(1: 2,000)$. Images were captured using a Nikon C1 confocal device mounted on a Nikon Eclipse E800 microscope with a $60 \times$ Plan Apo (NA 1.4) oil objective lens, E7-C1 software, and $\mathrm{UV}$, Argon, and $\mathrm{He} / \mathrm{Ne}$ lasers exciting at 408, 488, and $543 \mathrm{~nm}$ and emitting at 404, 500-530, and 555-615 nm, respectively.

\section{Antibodies}

The primary antibodies used were as follows: mouse anti-O4 (1:1 of a hybridoma cell culture supernatant; a generous gift from Dr. Stephen Back, Oregon Health and Science University), rabbit anti-TrkA (1:250; Abcam), mouse anti-p75 (1:750; Promega), chicken anti-TH (1:250; Aves), rabbit anti-Ki67 (1:200; Novacastra), rabbit anti-CNTFRa (1:30; a generous gift from Dr. Hermann Rohrer of the Max Planck Institute for Brain Research, Frankfurt, Germany), mouse anti-3A10 (neurofilament associated antigen, 1: 1; Development Studies Hybridoma Bank), and sheep anti-BrdU (1:100; Biodesign). The secondary antibodies were donkey antirabbit Alexa 488 (1:1,666; Invitrogen), donkey anti-mouse cy3 (1: 1,000; Jackson), donkey anti-rabbit cy3 (1:1,000; Jackson), and donkey anti-goat Alexa 488 (1:1,000; Invitrogen).

\section{Cell Culture}

All cells were grown at $37^{\circ} \mathrm{C}$ in $5 \% \mathrm{CO}_{2}$. To obtain TH-MYCN tumor cells, tumors were removed from homozygous TH-MYCN mice at 35 days of age and mechanically dissociated by triturating in warm modified Puck's solution with glucose $\left(\mathrm{a} \mathrm{Ca}^{2+}-\right.$ and $\mathrm{Mg}^{2+}-$ free balanced salt solution) to obtain a single-cell suspension. Cells were then plated on coverslips (Fisher Scientific) coated with poly-D-lysine $(0.5 \mathrm{mg} / \mathrm{ml}$; Sigma $)$ and laminin $(0.02 \mathrm{mg} / \mathrm{ml}$; purified in the Nishi laboratory from Engelbreth-Holm-Swarm tumors grown subcutaneously in C57Bl6 mice) at 50,000 cells/well in 24well tissue culture plates (Falcon). They were grown in $20 \mathrm{U} / \mathrm{ml}$ penicillin, $20 \mathrm{mg} / \mathrm{ml}$ streptomycin, $2 \mathrm{mM} \mathrm{L}$-glutamine, and $6 \mathrm{mg} /$ $\mathrm{ml}$ glucose in modified $\mathrm{L}_{15 \mathrm{CO}_{2}}$ supplemented with B27 (1:50; In- 
vitrogen). Growth factors were added upon plating and consisted of the following: $\operatorname{CNTF}(5,1,0.5$, and $0.25 \mathrm{ng} / \mathrm{ml}$; Alomone), brainderived neurotrophic factor (BDNF; $10 \mathrm{ng} / \mathrm{ml}$; R\&D), leukemia inhibitory factor (LIF; $10 \mathrm{ng} / \mathrm{ml}$; R\&D), 7s NGF $(1 \mu \mathrm{g} / \mathrm{ml}$; Alomone), neurotrophin 3 (NT-3; $30 \mathrm{ng} / \mathrm{ml}$; R\&D), and glial cell-derived neurotrophic factor (GDNF; $10 \mathrm{ng} / \mathrm{ml}$; PeproTech). For bromodeoxyuridine (BrdU) experiments, $10 \mu \mathrm{M}$ BrdU was added $2 \mathrm{~h}$ after plating and then washed out $24 \mathrm{~h}$ later.

\section{Quantification of Process Outgrowth, Proliferation, and}

Neuronal Marker Expression

Following staining, process outgrowth and proliferation were quantified using a Nikon Eclipse E800 microscope connected to a computer equipped with StereoInvestigator and Neurolucida software (MBF Bioscience, Williston, Vt., USA) in the Center of Biomedical Research Excellence (COBRE) Molecular Cellular Core Facility. Briefly, after creating a defined counting area, the fractionator program of StereoInvestigator selects random views within that area in which the observer counts the number of morphologically intact cells to get an estimate of the total population. Process outgrowth was measured using Neurolucida. For each coverslip, 16 random views were selected in which to measure process length. All neurite processes falling within each of the 16 random fields of view were traced. Traced neurites in any given field of view came from multiple different tumor cells, many of which may fall out of the field of view given the extensive length of some processes (see online suppl. fig. 1 for example of tracings; for all online suppl. material, see www.karger.com/doi/10.1159/000365281). In order to derive the process length per cell value for each condition, the total process length from the 16 random views determined in Neurolucida was divided by the cell population as determined using StereoInvestigator. For the BrdU-Ki67 and TH-Ki67 studies, neurons stained above background were counted as positive for the indicated markers using the fractionator program of StereoInvestigator.

\section{RNA Extraction and $q P C R$}

For RNA extraction from TH-MYCN tumor cells, cells were lysed directly into TRI Reagent (Molecular Research Center) following dissociation, and RNA was isolated using the manufacturer's protocol. One microgram of RNA was transcribed to cDNA using superscript III (Invitrogen) and random hexamer priming (Invitrogen). cDNA was then diluted 1:5, and CNTFRa and 18S RNA expression were quantified using FAM/BHQ-labeled primer/TaqMan probe mixes (ABI) and run on an ABI 7700 machine in the Molecular Cellular Core operated by the COBRE in the Neuroscience Department at the University of Vermont. Cycle threshold $(\mathrm{Ct})$ values for the target gene (CNTFR $\alpha$ ) were normalized to the control gene

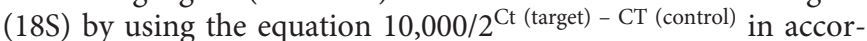
dance with $\mathrm{ABI}$ instructions. Mean values and standard deviations were calculated for each experiment. RNA samples from 4 superior cervical ganglion/tumor pairs from 4 separate mice were quantified.

\section{Results}

\section{Tumor Development in TH-MYCN Mice}

All the homozygous TH-MYCN mice examined formed palpable tumors by an average of $50 \pm 1.0$ days of
Table 1. Tumor development in homozygous TH-MYCN mice

\begin{tabular}{|c|c|c|c|}
\hline Mouse & Sex & $\begin{array}{l}\text { Age at tumor } \\
\text { detection, days }\end{array}$ & Notes \\
\hline $1033-3$ & $\mathrm{~F}$ & 50 & Abdominal tumor \\
\hline $1039-1$ & $\mathrm{~F}$ & 50 & Abdominal tumor \\
\hline $1042-1$ & M & 54 & Abdominal tumor \\
\hline $1042-2$ & M & 52 & Abdominal tumor \\
\hline $1042-3$ & M & 49 & Abdominal tumor \\
\hline $1048-2$ & M & 48 & Abdominal tumor \\
\hline $1048-7$ & M & 44 & Abdominal tumor \\
\hline $1051-2$ & M & 51 & Abdominal tumor \\
\hline $1051-5$ & M & 51 & Abdominal tumor \\
\hline $1051-7$ & M & 52 & $\begin{array}{l}\text { Abdominal tumor, left } \\
\text { SCG } 4 \times \text { larger than right }\end{array}$ \\
\hline $1052-1$ & M & 51 & Abdominal tumor \\
\hline $1052-4$ & M & 50 & $\begin{array}{l}\text { Abdominal tumor, right } \\
\text { SCG } 2 \times \text { larger than left }\end{array}$ \\
\hline 1054-1 & $\mathrm{F}$ & 49 & $\begin{array}{l}\text { Abdominal as well as } \\
\text { sympathetic chain tumor }\end{array}$ \\
\hline 1054-2 & M & 42 & Abdominal tumor \\
\hline Average & & $50 \pm 1$ & \\
\hline
\end{tabular}

Homozygous TH-MYCN 129/SvJ mice were sacrificed at the indicated ages after palpable tumors were detected. They were checked daily for tumor development. The notes indicate where the tumor was located and whether any other tumors were observed in the animal. SCG $=$ Superior cervical ganglion.

postnatal (PN) age (table 1). Tumors were large, highly angiogenic, and formed predominantly in the abdomen, as in hemizygous mice [21]. In 2 of 14 mice, an asymmetrical enlargement of the superior cervical ganglion was also found. In 1 mouse, along with a tumor at or near the celiac ganglion, a separate tumor developing along the lower sympathetic chain was also observed. When examined at PN35, considerably smaller, yet readily identifiable, tumors could always be found at the site of the celiac/superior mesenteric complex, suggesting that virtually all of the larger abdominal tumors formed at this site. These tumors were approximately 3-5 times the size of the normal ganglion, well circumscribed, avascular, and homogeneously white-tan in appearance. As in the larger tumors harvested when palpable, tumor tissue at this earlier time point completely engulfed the normal ganglion, and less of the tissue was necrotic as often observed in larger tumors. These tumors could be readily differentiated from the normal ganglion.

While a minority of cells in sections from tumors harvested at PN35 express strong $\mathrm{TH}$ immunoreactivity (fig. 1a, d, g), many of the cells express CNTFRa immu- 

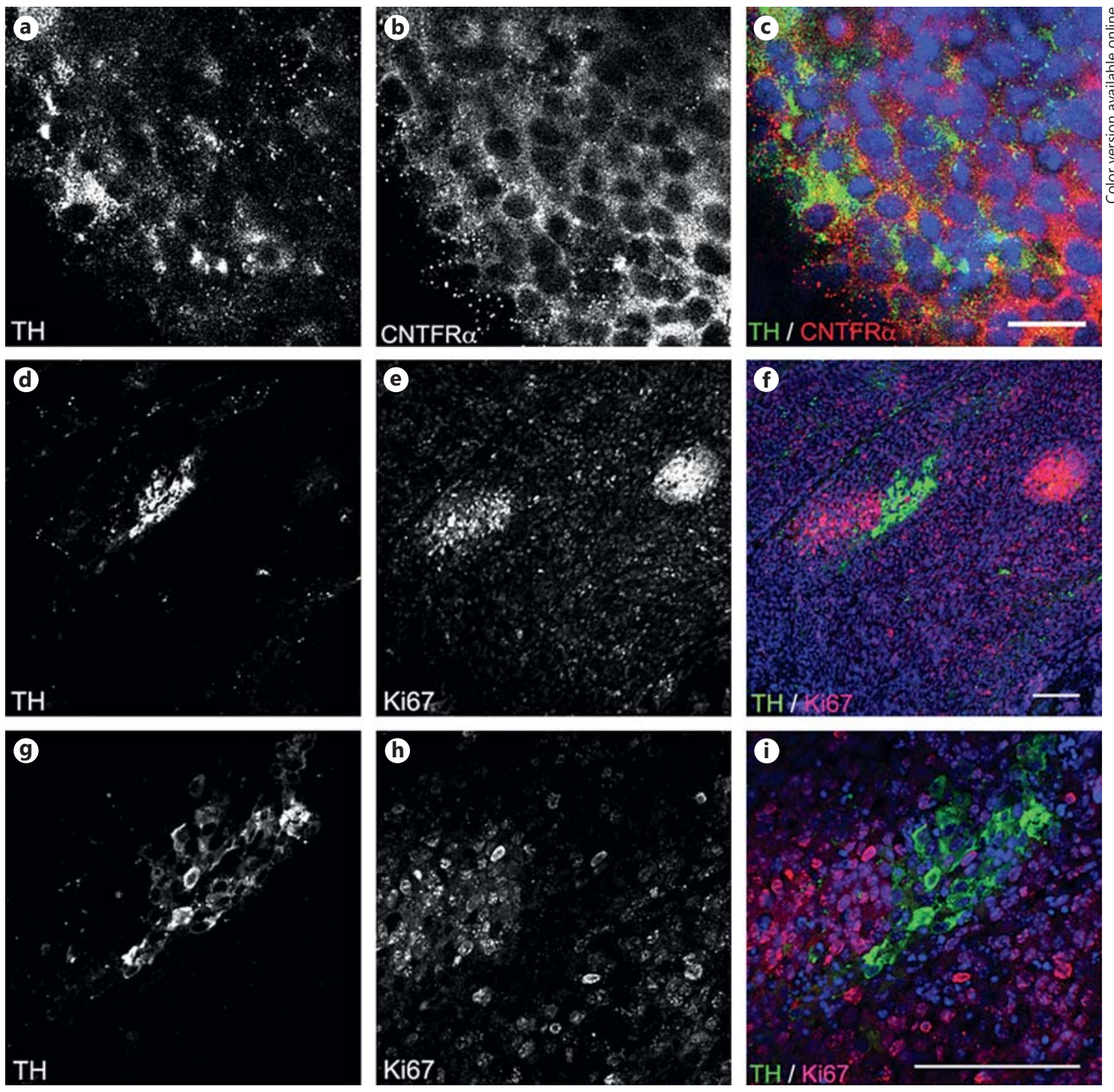

Fig. 1. CNTFRa expression in TH-MYCN tumor cells in vivo. a-c $\times 60$ confocal image of a tumor section stained for $\mathrm{TH}$ (a; green in merged image c; colors refer to the online version only) and CNTFRa (b; red in merged image $\mathbf{c})$. Many tumor cells abundantly express the CNTF receptor in vivo, while few cells express $\mathrm{TH}$. Calibration bar $=10 \mu \mathrm{m}$. $\mathbf{d}-\mathbf{f} \times 20$ confocal image of a tumor section

noreactivity (fig. 1b). A large majority of cells in $\mathrm{TH}$ MYCN tumors also stain strongly for Ki67, indicating a high rate of proliferation (fig. 1e, h) and confirming that the tissue we isolated was tumor in origin rather than postmitotic ganglionic neurons. Additionally, the levels of CNTFRa mRNA expressed in tumors were not significantly different from those expressed in the superior cervical ganglion ( $32.8 \pm 3.6$ vs. $31.0 \pm 6.0$ arbitrary units; Student's t test; $\mathrm{n}=4$ independent assays; error $=$ SEM). stained for TH (d; green in merged image f) and Ki67 (e; red in merged image f) isolated from a 35-day-old homozygous TH$M Y C N$ mouse. Calibration bar $=100 \mu \mathrm{m}$. g-i $\times 60$ confocal image of the same field displayed in $\mathbf{d}-\mathbf{f}$ showing that the TH-positive tumor cells (g; green in merged image i) do not express Ki67 (h; red in the merged image i). Calibration bar $=100 \mu \mathrm{m}$.
In order to investigate the effects of CNTF, PN35 tumors were mechanically dissociated and placed in cell culture. Upon plating, tumor cells are small, round, and undifferentiated, and they lack cell processes. Occasional cells are TH positive (fig. $2 \mathrm{a}$ ), and $70 \%$ of the acutely isolated cells express CNTFRa (fig. 2b-d). The percentage of CNTFRa-positive cells significantly increases after 3 days in culture, regardless of CNTF treatment (fig. 2d; p < $0.0001)$. TrkA immunoreactivity could not be detected. A 


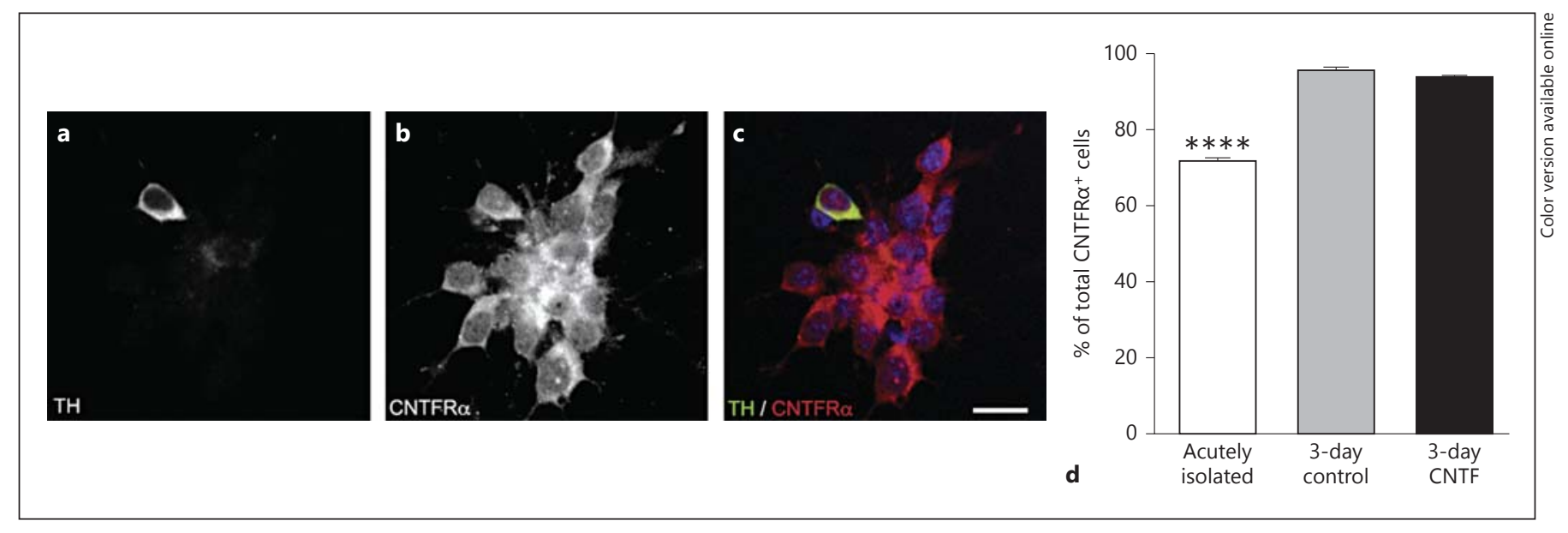

Fig. 2. CNTFRa expression in cultured TH-MYCN tumor cells. a-c $\times 60$ confocal image of cultured TH-MYCN tumor cells stained for TH (a; green in merged image $\mathbf{c}$ ) and CNTFRa (b; red in merged image $\mathbf{c}$ ). Calibration bar $=10 \mu \mathrm{m}$. d Quantification of CNTFRa expression in acutely isolated, cultured tumor cells and

minority of cells are immunoreactive for the early glial precursor marker 04 , and essentially all of the acutely isolated cells express Ki67 (fig. 6b), indicating that the only cells that survive the mechanical dissociation are small, dividing cells. The cells were also not positive for p75NTR and, to confirm this, we could not detect p75 with RTPCR, even though p75 could be detected in RNA extracted from the superior cervical ganglion of the affected mice (data not shown).

\section{CNTF Promotes the Differentiation of TH-MYCN \\ Tumor Cells in vitro}

Tumor cell cultures were then treated with BDNF (10 $\mathrm{ng} / \mathrm{ml})$, CNTF ( $5 \mathrm{ng} / \mathrm{ml})$, GDNF (10 ng/ml), LIF (10 ng/ $\mathrm{ml}), 7 \mathrm{~s}$ NGF $(1 \mu \mathrm{g} / \mathrm{ml}), \mathrm{NT}-3(30 \mathrm{ng} / \mathrm{ml})$, and a combination of $7 \mathrm{~s} \mathrm{NGF}(1 \mu \mathrm{g} / \mathrm{ml})$ and NT-3 $(30 \mathrm{ng} / \mathrm{ml})$. To measure differentiation, cultures were fixed and stained with $\mathrm{mAb} 3 \mathrm{~A} 10$, which recognizes a neurofilament-associated antigen that is neuron specific [22]. The lengths of the $3 \mathrm{~A} 10$-positive neurites were then quantified. After 4 days in vitro, treatment with CNTF and LIF, but not other growth factors, promotes approximately a 4 -fold increase in process outgrowth (fig. 3a, gray bars; $\mathrm{p}<0.01$ ) as well as a $15 \%$ reduction in proliferation, as measured by Ki67 staining (fig. 3a, black bars; $\mathrm{p}<0.05$ ). After only 3 days in vitro, CNTF-treated tumor cells are visibly more differentiated than untreated cells (fig. 3b, c; online suppl. fig. 1). While both CNTF and LIF signaling involves the LIFR $\beta$ and GP130 receptor signaling subunits, CNTF sig- tumor cells treated with CNTF for 3 days in vitro $(5 \mathrm{ng} / \mathrm{ml})$ or not. There is a significant increase in CNTFRa expression from day 0 to day $3(* * * * \mathrm{p}<0.0001$, analysis of variance; $\mathrm{n}=4)$. However, 3 days of CNTF treatment has no effect on CNTFRa expression. Error bars $=$ SEM.

naling requires the additional presence of a CNTFRa subunit, a glycosyl-phosphoinositide-linked coreceptor commonly expressed in cells of both the peripheral and central nervous system [23], which binds CNTF [24]. Therefore, the differentiating effects of CNTF rather than of LIF on TH-MYCN tumor cells were further investigated.

When quantifying the CNTF-induced process outgrowth and inhibition of proliferation after 1,2, and 3 days of CNTF treatment, these CNTF-induced effects reach significance after 3 days of treatment (fig. 4a, c; p < 0.0001 ). No significant changes in cell number are observed over the time course of CNTF treatment (fig. 4e). The effects of CNTF are concentration dependent $(\mathrm{p}<$ 0.01 ), with an $\mathrm{EC}_{50}$ of approximately $0.4 \mathrm{ng} / \mathrm{ml}$ for the effects on neurite outgrowth (fig. $4 \mathrm{~b}$ ) and proliferation (fig. 4d), similar to the $\mathrm{EC}_{50}$ observed in the CNTF-induced decreases in proliferation in embryonic chicken sympathetic neurons [25]. Consistent with the time course experiments, there was no concentration-dependent effect of CNTF on cell number (fig. 4f).

\section{CNTF Promotes the Withdrawal of Proliferating Cells} from the Cell Cycle

To determine whether CNTF induces actively dividing cells to withdraw from the cell cycle, we incubated cells in BrdU $(10 \mu \mathrm{M})$ to label the DNA of all dividing cells, and cells were treated with or without CNTF. After $24 \mathrm{~h}$, the BrdU was washed out, and the media and CNTF were re- 
Fig. 3. Growth factor effects on the process outgrowth and proliferation of TH-MYCN tumor cells in culture. a CNTF $(5 \mathrm{ng} / \mathrm{ml})$ and LIF (10 $\mathrm{ng} / \mathrm{ml})$, which both activate the CNTF receptor, significantly increase process outgrowth (graybars; ${ }^{* *} \mathrm{p}<0.01$, analysis of variance; $n=5$ ) and inhibit proliferation (black bars; ${ }^{*} \mathrm{p}<0.05$, analysis of variance; $n=5$ ) in tumor cells derived from TH-MYCN mice after 4 days in vitro compared with control, BDNF (10 ng/ml), GDNF (10 ng/ml), NGF (1 $\mu \mathrm{g} / \mathrm{ml})$, NT-3 (30 ng/ml), and NGF and NT-3. Error bars $=$ SEM. $\mathbf{b}, \mathbf{c} \times 60$ confocal images demonstrating CNTF-induced process outgrowth after 3 days in TH-MYCN tumor cells stained for $3 \mathrm{~A} 10$, a neurofilament-associated antigen. Image brightness enhanced to highlight cell processes. Calibration bar $=100 \mu \mathrm{m}$.

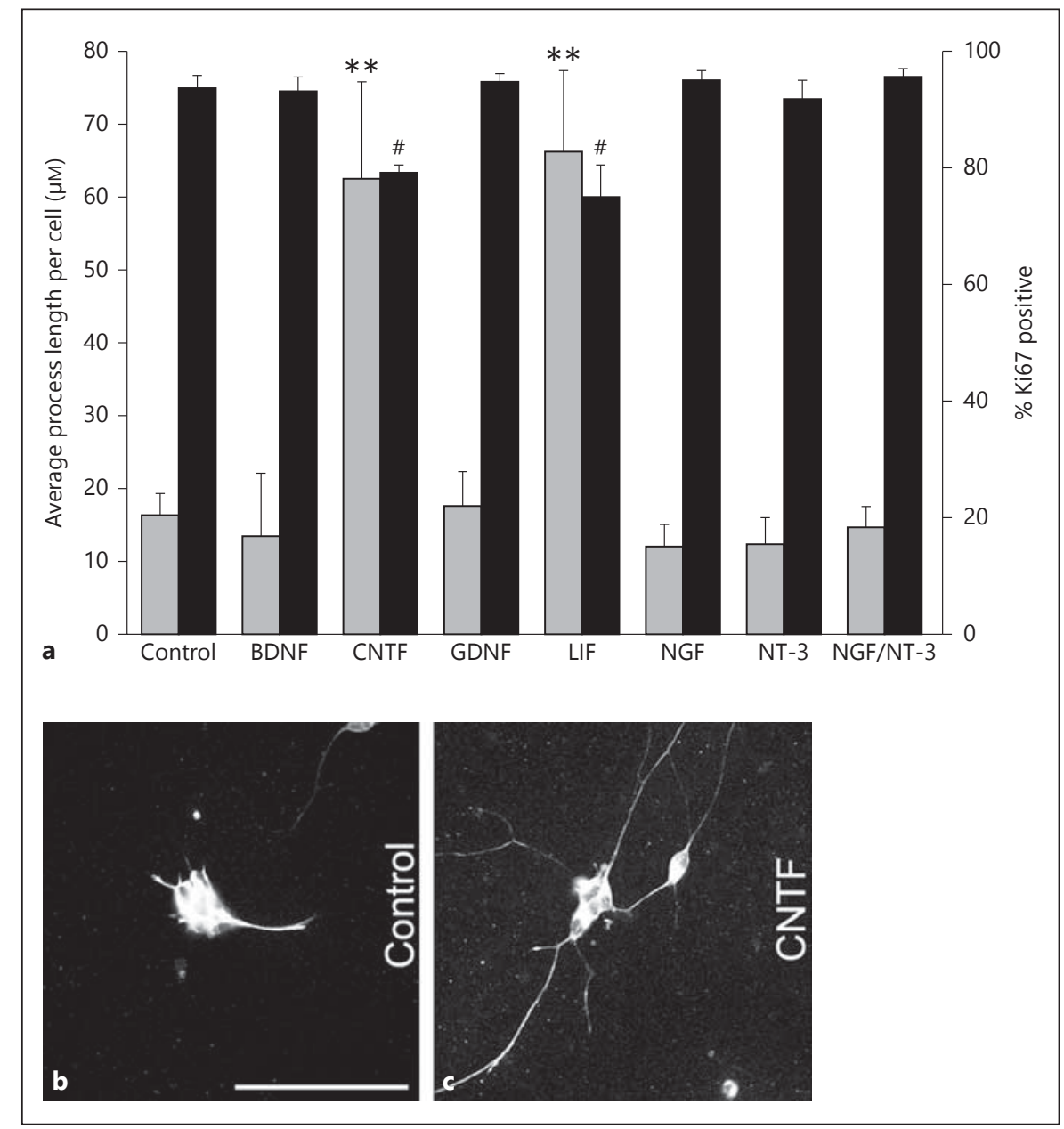

placed. After an additional $48 \mathrm{~h}$ in culture without BrdU, tumor cells were fixed and stained for BrdU (fig. 5b, d) and for Ki67, which is a marker of cells that remain in the cell cycle (fig. 5c, e) [26]. Although there is no change in the total number of cells that stain with BrdU and/or Ki67 (fig. 5f), CNTF treatment causes an approximately $30 \%$ decrease in the percentage of BrdU-positive cells staining positive for Ki67 (fig. 5g; p < 0.0001). That is, cells that were originally dividing during day 1 in cell culture, and therefore were marked by BrdU, lost Ki67 immunoreactivity if treated with CNTF, indicating that formerly proliferating cells had withdrawn from the cell cycle.

We also examined TH expression in combination with Ki67 in tumor cells after $2 \mathrm{~h}$ in culture ('acutely isolated') and in cells treated with saline or CNTF for 3 days. Overall, the total cell numbers in these cultures do not significantly differ (fig. 6a). However, there is a significant increase in the percentage of cells that are immunoreactive for TH, but not Ki67, in cells treated with CNTF com- pared with both acutely isolated and untreated tumor cells (fig. 6b). Additionally, in cells treated with CNTF compared with untreated tumor cells, there is a significant decrease in the percentage of cells that are immunoreactive for both $\mathrm{TH}$ and $\mathrm{Ki} 67$, and in the percentage of cells that are immunoreactive for Ki67 but not TH. Therefore, the percentage of cells that were TH positive and Ki67 negative (and, hence, nonproliferating) increased dramatically with CNTF (fig. 6b), suggesting that CNTF promotes withdrawal from the cell cycle and induces the expression of $\mathrm{TH}$.

\section{Discussion}

The principal finding of this study is that the growth factor CNTF induces cell cycle withdrawal and promotes the differentiation of TH-MYCN tumor cells into an early neuronal phenotype that includes the expression of 
Fig. 4. CNTF effects are time and concentration dependent. Error bars = SEM. a, c CNTF ( ) significantly increases process outgrowth (a) and inhibits proliferation (c) over control $(\mathrm{O})$ after 3 days in culture (**** $\mathrm{p}<0.0001$, analysis of variance; $\mathrm{n}=$ 4). e CNTF treatment has no effect on total cell number over the 3-day culture period. b, d CNTF-induced process outgrowth (b; ${ }^{* *} \mathrm{p}<0.01$, analysis of variance; $\left.\mathrm{n}=4\right)$ and decrease in proliferation $\left(\mathbf{d} ;{ }^{* * *} \mathrm{p}<0.001\right.$, analysis of variance; $n=4$ ) are concentration dependent after 3 days in vitro. The $\mathrm{EC}_{50}$ for both effects is approximately $0.4 \mathrm{ng} / \mathrm{ml}$. $\mathbf{f}$ There is no concentration-dependent effect of CNTF on tumor cell number after 3 days in vitro.

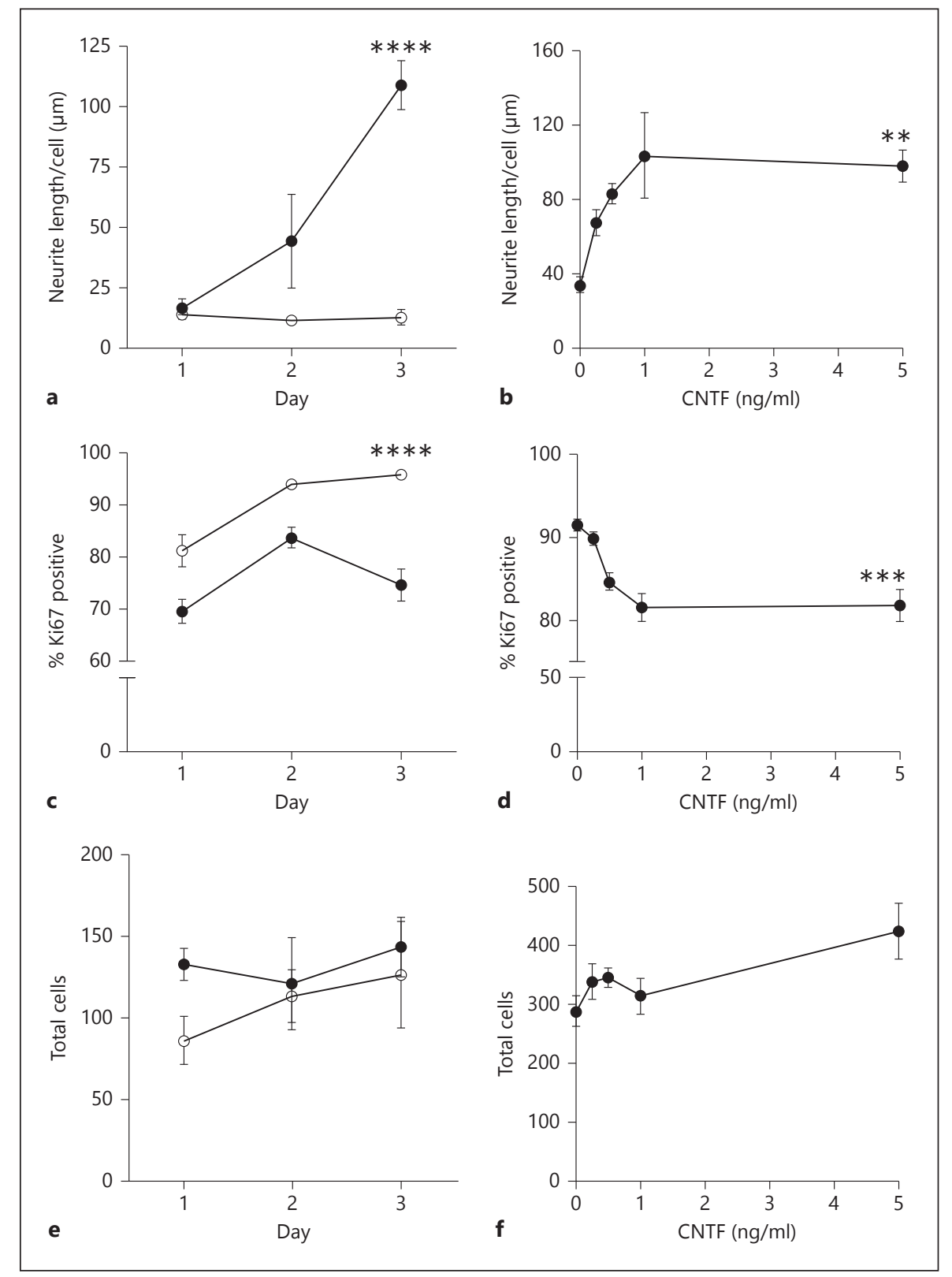

neurofilament-associated protein, extensive neurite outgrowth, and the expression of TH. Virtually all cells isolated from the tumor were Ki67 positive, indicating that they were proliferating, and the majority of these cells expressed CNTFRa. Up to $40 \%$ of the cells in culture responded to CNTF, suggesting that CNTF responsiveness is not limited to a minor population of neurons hidden in the tumor. These effects were not observed with other neurotrophic factors known to promote the survival of sympathetic or sensory neurons (BDNF, NGF, NT-3, or GDNF). Taken together, our data suggest that a further understanding of the molecular mechanisms involved in neuropoietic cytokine signaling could provide a potential mechanism for promoting differentiation in neuroblastoma.

The effect of CNTF we observed on dividing THMYCN cells is similar to the effect of CNTF on proliferating, cultured embryonic day (E)7 chicken sympathetic neuroblasts [25]. CNTF causes an approximately $30 \%$ reduction in the number of proliferating cells in both embryonic sympathetic neurons and TH-MYCN tumor cells. In addition, NGF and BDNF have no effect on TH-MYCN 
Fig. 5. CNTF causes proliferating $\mathrm{TH}-$ MYCN tumor cells to withdraw from the cell cycle. a On day 0, tumor cells were plated in the presence of BrdU $(10 \mu \mathrm{M})$ and treated with CNTF or not; 24 h later, BrdU was washed out and fresh media and CNTF were added. After another $48 \mathrm{~h}$ in culture, the tumor cells were fixed and stained for BrdU and Ki67. b-e A similar number of untreated (b) and CNTF-treated (d) tumor cells are dividing in culture between day 0 and day 1, indicated by incorporation of BrdU. At the 3-day time point, a difference in proliferation is observed between untreated (c) and CNTF-treated (e) tumor cells, indicated by Ki67 staining. A number of CNTF-treated tumor cells withdraw from the cell cycle, as shown by staining for BrdU but not Ki67 (arrowheads in d, e), while the majority of untreated cells remain dividing at both time points. Calibration bar $=10 \mu \mathrm{m} . \mathbf{f}, \mathbf{g}$ Although there is no difference in total cells staining for BrdU and/or Ki67 (f), quantification of the percentage of BrdU cells that stain positive for Ki67 shows a significant decrease in Ki67 staining in CNTF-treated tumor cells (g; **** $\mathrm{p}<0.0001$, Student's t test; $\mathrm{n}=4$ ). Error bars $=$ SEM.

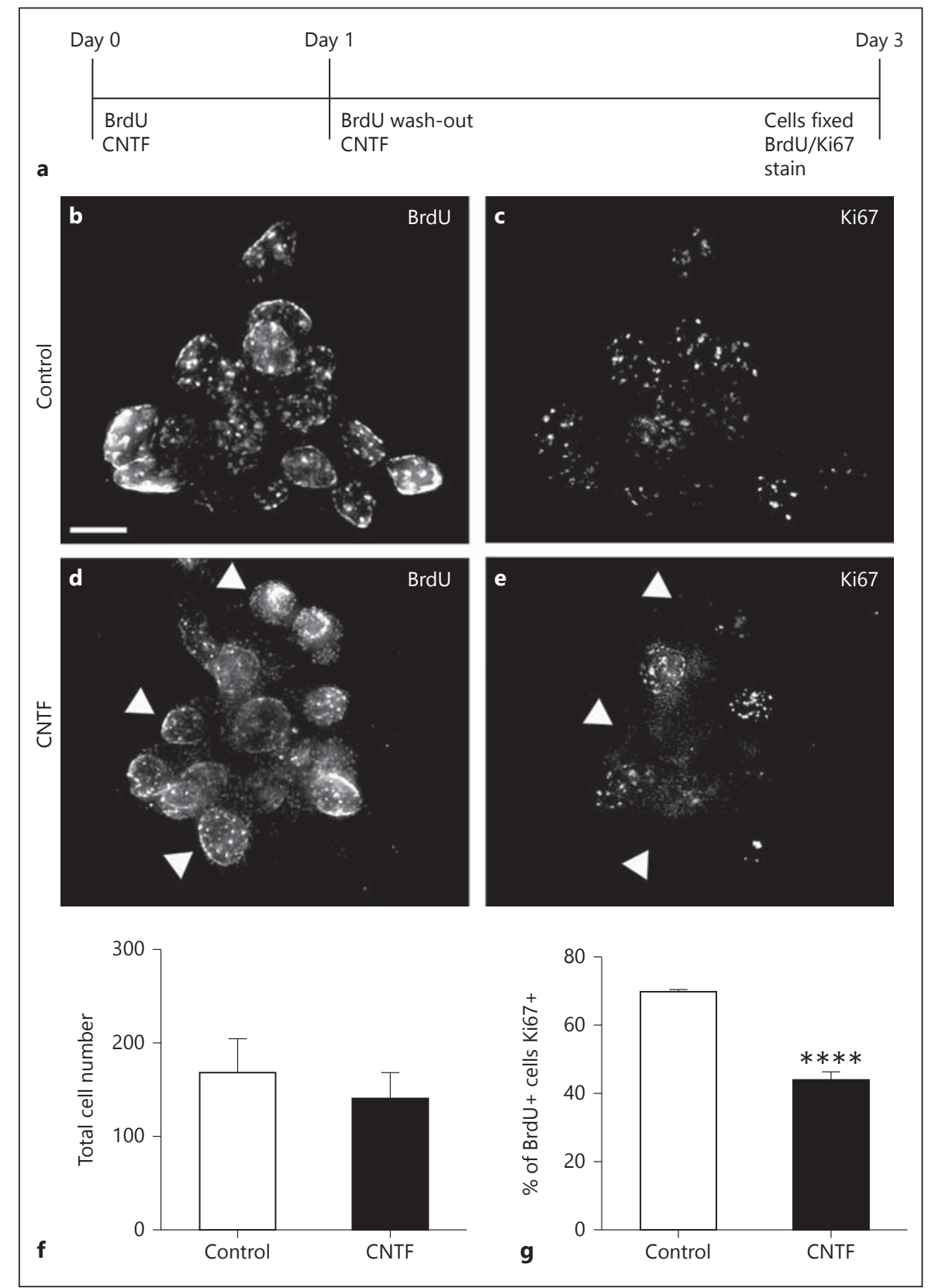

tumor cell proliferation as observed with E7 chicken sympathetic progenitors. Although CNTF is able to decrease proliferation in sympathetic neuroblasts and TH-MYCN tumor cells, the effects of CNTF on sympathetic markers of differentiation differ between these two systems. In E7 chicken sympathetic progenitors, CNTF promotes the expression of vasoactive intestinal peptide, while no such effect is observed in TH-MYCN tumor cells (data not shown), suggesting that TH-MYCN transformation alters the response of tumor cells to CNTF. In another model of sympathetic differentiation, a sympathoadrenal progenitor cell line (MAH) which is able to differentiate into chromaffin-like and sympathetic neuron-like cells, CNTF promotes terminal differentiation into a neurofilament-positive sympathetic phenotype in vivo [27], similar to what we have observed here.

While tumor cells from the TH-MYCN mouse model of neuroblastoma respond to CNTF treatment by differentiating, responses of CNTFRa-expressing human neuroblastoma cells to CNTF are variable. Consistent with 


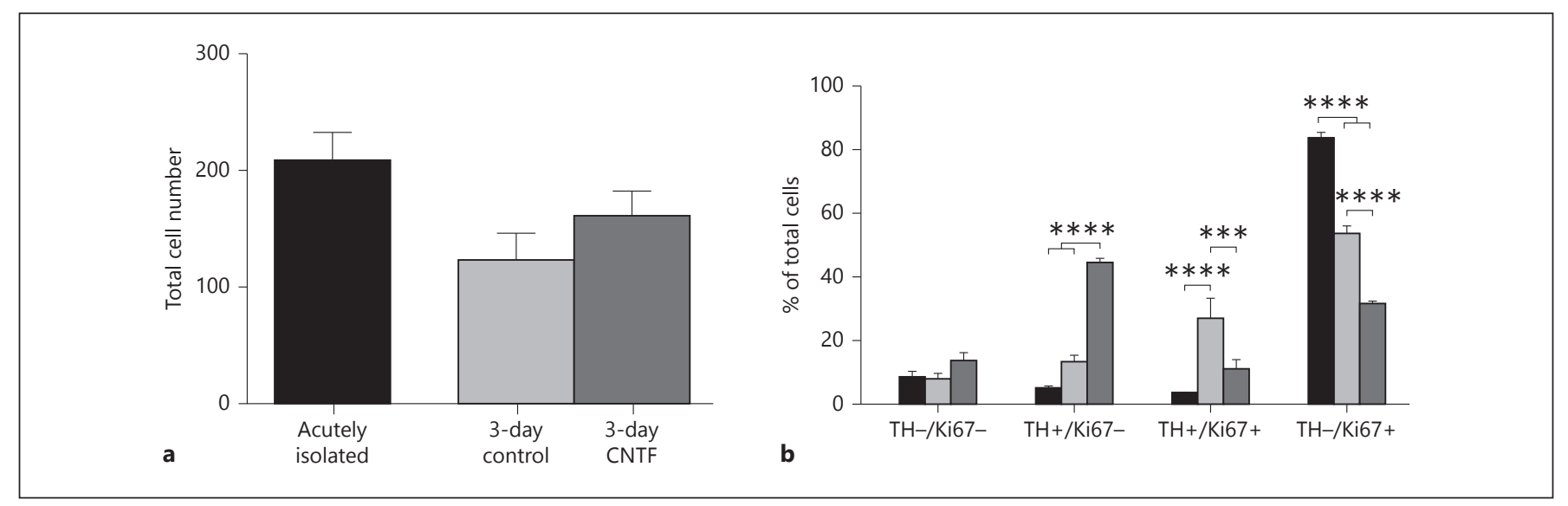

Fig. 6. TH and Ki67 staining in cultured TH-MYCN tumor cells. a Total number of tumor cells after $2 \mathrm{~h}$ in culture (acutely isolated; black bars) versus the total number seen after 3 days in controltreated (light gray) and CNTF-treated ( $5 \mathrm{ng} / \mathrm{ml}$; dark gray) cultures. There is no significant difference between the 3 culture conditions (one-way analysis of variance; $\mathrm{n}=4$ cultures for each condition). b Percent of total cells from the condition described in a that are TH and Ki67 positive. Percentages were analyzed by two-way analysis of variance and pair-wise comparisons were done using Tukey's post hoc test. ${ }^{* * *} \mathrm{p}<0.001,{ }^{* * * *} \mathrm{p}<0.0001$. Error bars $=$ SEM. what we observe in this study, the $M Y C N$-amplified neuroblastoma cell lines LA-N-2 and SK-N-BE respond to CNTF treatment with enhanced neurite outgrowth, marked by an increased number of tumor cells with neurites, and increased neurite length [28]. However, in the neuroblastoma cell line SY5Y, from which the CNTFRa receptor was originally cloned due to its abundant expression in these cells [29], treatment with CNTF activates the JAK-STAT pathways downstream of CNTFRa but does not cause tumor cell differentiation [28,30], perhaps due to a disruption of downstream pathways leading to differentiation. Furthermore, although CNTF treatment induces the expression of the neurotrophin receptor TrkA in both GOTO and HTLA230 neuroblastoma cell lines, subsequent treatment with the TrkA ligand NGF results in proliferation in GOTO cells but differentiation in HTLA230 cells [31].

In the TH-MYCN mouse model, the overexpression of $M Y C N$ in sympathoadrenal neural progenitors likely causes cells to ignore cell cycle checkpoints and allows an accumulation of DNA mutations, leading to a transformed phenotype. While N-myc was first identified in neuroblastoma [32], it is now well known that this transcription factor is selectively expressed in virtually all dividing neural progenitors [33]. When cells commence neural differentiation, $\mathrm{N}-m y c$ is downregulated, and the cells undergo terminal withdrawal from mitosis. If N-myc continues to be expressed at high levels, continued proliferation likely leads to a transformed phenotype. Such a process would seem to lead to tumors with heterogeneous phenotypes; yet, our studies have shown that all tumors formed in this mouse model contain cells that respond to CNTF but not to other neurotrophic factors typical of sympathetic neurons (NT-3, NGF, and GDNF). Thus, MYCN overexpression differentially affects responsiveness to neurotrophic molecules rather than causing a complete dedifferentiation of the progenitors.

Based on our studies, we suggest that MYCN overexpression results in a propagation of an immature, dividing sympathoadrenal phenotype. This is supported by the observation that MYCN promotes the expansion of Phox2B-positive neuronal progenitors in this mouse model [17]. We suggest that a subset of $M Y C N$-amplified human neuroblastoma tumors may also be the same and retain the capacity to respond to CNTF. In fact, neuroblastoma patients whose tumors express high mRNA levels of either CNTF or CNTFRa have improved survival over patients whose tumors have a low expression of the two transcripts (http://home.ccr.cancer.gov/oncology/ oncogenomics/).

\section{Acknowledgements}

The authors would like to thank Chelsea Carman and Eric Gonzalez for technical assistance as well as Felix Eckenstein for advice. Portions of this study were conducted in the Neuroscience COBRE Molecular Cellular Core and the Imaging and Physiology Core at the University of Vermont (P30 GM 103498). Funding for this project was made possible by Alex's Lemonade Stand Foundation and NIH R21 NS076969. 


\section{References}

1 Maris JM, Hogarty MD, Bagatell R, Cohn SL: Neuroblastoma. Lancet 2007;369:2106-2120.

-2 Nakagawara A, Azar CG, Scavarda NJ, Brodeur GM: Expression and function of TRK-B and BDNF in human neuroblastomas. Mol Cell Biol 1994;14:759-767.

-3 Lavenius E, Gestblom C, Johansson I, Nanberg E, Pahlman S: Transfection of TRK-A into human neuroblastoma cells restores their ability to differentiate in response to nerve growth factor. Cell Growth Differ 1995;6: 727-736.

4 Ho R, Eggert A, Hishiki T, Minturn JE, Ikegaki N, Foster P, Camoratto AM, Evans AE, Brodeur GM: Resistance to chemotherapy mediated by TrkB in neuroblastomas. Cancer Res 2002;62:6462-6466.

$\checkmark 5$ Ho R, Minturn JE, Hishiki T, Zhao H, Wang Q, Cnaan A, Maris J, Evans AE, Brodeur GM: Proliferation of human neuroblastomas mediated by the epidermal growth factor receptor. Cancer Res 2005;65:9868-9875.

$\checkmark 6$ Cohen PS, Letterio JJ, Gaetano C, Chan J, Matsumoto K, Sporn MB, Thiele CJ: Induction of transforming growth factor beta 1 and its receptors during all-trans-retinoic acid (RA) treatment of RA-responsive human neuroblastoma cell lines. Cancer Res 1995;55: 2380-2386.

$>7$ Davis S, Aldrich TH, Stahl N, Pan L, Taga T, Kishimoto T, Ip NY, Yancopoulos GD: LIFR $\beta$ and GP130 as heterodimerizing signal transducers of the tripartite CNTF receptor. Science 1993;260:1805-1808.

$>8$ Eckenstein FP, Esch F, Holbert T, Blacher RW, Nishi R: Purification and characterization of a trophic factor for embryonic peripheral neurons: comparison with fibroblast growth factors. Neuron 1990;4:623-631.

$>9$ Ip NY, Li YP, van de Stadt I, Panayotatos N, Alderson RF, Lindsay RM: Ciliary neurotrophic factor enhances neuronal survival in embryonic rat hippocampal cultures. J Neurosci 1991;11:3124-3134.

$>10$ Lehwalder D, Jeffrey PL, Unsicker K: Survival of purified embryonic chick retinal ganglion cells in the presence of neurotrophic factors. J Neurosci Res 1989;24:329-337.

-11 Miller RG, Bryan WW, Dietz MA, Munsat TL, Petajan JH, Smith SA, Goodpasture JC: Toxicity and tolerability of recombinant human ciliary neurotrophic factor in patients with amyotrophic lateral sclerosis. Neurology 1996;47:1329-1331.
12 Stöckli KA, Lottspeich F, Sendtner M, Masiakowski P, Carroll P, Götz R, Lindholm D, Thoenen H: Molecular cloning, expression and regional distribution of rat ciliary neurotrophic factor. Nature 1989;342:920-923.

$>13$ Kirsch M, Hofmann HD: Expression of ciliary neurotrophic factor receptor mRNA and protein in the early postnatal and adult rat nervous system. Neurosci Lett 1994;180:163166.

14 Finn T, Nishi R: Does ciliary neurotrophic factor serve a different function in the rat versus the chicken? Perspect Dev Neurobiol 1996;4:91-99.

15 Weiss WA, Aldape K, Mohapatra G, Feuerstein BG, Bishop JM: Targeted expression of MYCN causes neuroblastoma in transgenic mice. EMBO J 1997;16:2985-2995.

16 Hansford LM, Thomas WD, Keating JM, Burkhart CA, Peaston AE, Norris MD, Haber M, Armati PJ, Weiss WA, Marshall GM: Mechanisms of embryonal tumor initiation: distinct roles for MycN expression and MYCN amplification. Proc Natl Acad Sci USA 2004;101: 12664-12669.

17 Alam G, Cui H, Shi H, Yang L, Ding J, Mao L, Maltese WA, Ding HF: MYCN promotes the expansion of Phox2B-positive neuronal progenitors to drive neuroblastoma development. Am J Pathol 2009;175:856-866.

18 Moore HC, Wood KM, Jackson MS, Lastowska MA, Hall D, Imrie H, Redfern CP, Lovat PE, Ponthan F, O’Toole K, Lunec J, Tweddle DA: Histological profile of tumours from MYCN transgenic mice. J Clin Pathol 2008; 61:1098-1103.

19 Hackett CS, Hodgson JG, Law ME, Fridlyand J, Osoegawa K, de Jong PJ, Nowak NJ, Pinkel D, Albertson DG, Jain A, Jenkins R, Gray JW, Weiss WA: Genome-wide array CGH analysis of murine neuroblastoma reveals distinct genomic aberrations which parallel those in human tumors. Cancer Res 2003;63:52665273.

20 Weiss WA, Godfrey T, Francisco C, Bishop JM: Genome-wide screen for allelic imbalance in a mouse model for neuroblastoma. Cancer Res 2000;60:2483-2487.

21 Chesler L, Goldenberg DD, Seales IT, SatchiFainaro R, Grimmer M, Collins R, Struett C, Nguyen KN, Kim G, Tihan T, Bao Y, Brekken RA, Bergers G, Folkman J, Weiss WA: Malignant progression and blockade of angiogenesis in a murine transgenic model of neuroblastoma. Cancer Res 2007;67:9435-9442.

-22 Storey KG, Crossley JM, de Robertis EM, Norris WE, Stern CD: Neural induction and regionalisation in the chick embryo. Development 1992;114:729-741.
23 Heller S, Ernsberger U, Rohrer H: Extrinsic signals in the developing nervous system: the role of neurokines during neurogenesis. Perspect Dev Neurobiol 1996;4:19-34.

-24 Ip NY, McClain J, Barrezueta NX, Aldrich TH, Pan L, Li Y, Wiegand SJ, Friedman B, Davis S, Yancopoulos GD: The alpha component of the CNTF receptor is required for signaling and defines potential CNTF targets in the adult and during development. Neuron 1993; 10:89-102.

25 Ernsberger U, Sendtner M, Rohrer H: Proliferation and differentiation of embryonic chick sympathetic neurons: effects of ciliary neurotrophic factor. Neuron 1989;2:12751284.

26 Yu CC, Woods AL, Levison DA: The assessment of cellular proliferation by immunohistochemistry: a review of currently available methods and their applications. Histochem J 1992;24:121-131.

27 Doering LC, Roder JC, Henderson JT: Ciliary neurotrophic factor promotes the terminal differentiation of $\mathrm{v}-m y c$ immortalized sympathoadrenal progenitor cells in vivo. Brain Res Dev Brain Res 1995;89:56-66.

28 Rossino P, Volpe G, Negro A, Callegaro L, Altruda F, Tarone G, Silengo L: Ciliary neurotrophic factor-induced gene expression in human neuroblastoma cell lines. Neurochem Res 1995;20:675-680.

29 Squinto SP, Aldrich TH, Lindsay RM, Morrissey DM, Panayotatos N, Bianco SM, Furth $\mathrm{ME}$, Yancopoulos GD: Identification of functional receptors for ciliary neurotrophic factor on neuronal cell lines and primary neurons. Neuron 1990;5:757-766.

30 Halvorsen SW, Malek R, Wang X, Jiang N: Ciliary neurotrophic factor regulates nicotinic acetylcholine receptors on human neuroblastoma cells. Neuropharmacology 1996;35: 257-265.

31 Bogenmann E, Peterson S, Maekawa K, Matsushima H: Regulation of NGF responsiveness in human neuroblastoma. Oncogene 1998;17:2367-2376.

>32 Slamon DJ, Boone TC, Seeger RC, Keith DE, Chazin V, Lee HC, Souza LM: Identification and characterization of the protein encoded by the human N-myc oncogene. Science 1986; 232:768-772.

33 Thomas WD, Raif A, Hansford L, Marshall G: $\mathrm{N}-m y c$ transcription molecule and oncoprotein. Int J Biochem Cell Biol 2004;36:771-775. 